\title{
WORD PATTERNS OF EGYPTIAN COLLOQUIAL ARABIC (ECA) IN EGYPTIAN SPEECH EVENTS
}

\author{
Arief Ma'nawi* \\ Amir Ma'ruf*
}

\begin{abstract}
Morphologically, Ammya Egyptian Arabic or Egyptian Colloquial Arabic (ECA) has specific word patterns. This study is aimed at describing morphological rules of the ECA. The data were obtained through interviews using recording technique with ECA speakers in Cairo and Ismaili. They were analyzed using distributional method, a method of data analysis to connect phenomena in a given language itself. The result indicates that ECA has some word patterns which have diverse manifestations. Such diversity can be seen that $V$ can be filled by the vowels [a], [i] and [u], C can be filled by all consonants in the ECA. In perfective verbs there are verbs patterns with singular first personal pronoun and singular masculine second personal pronoun affixes which can only be distinguished by context. A phenomenon was found that the ECA only has syllables of $C V, C V C$, CVVC, but not $C C V, C C V C$.
\end{abstract}

Key words: morphological, patterns of words, syllables, Egyptian Arabic, distributional

\begin{abstract}
ABSTRAK
Bahasa Arab amiyah Mesir atau Egyption Colloquial Arabic (ECA) secara morfologis mempunyai pola kata tertentu. Penelitian ini bertujuan mendeskripsikan kaidah morfologi bahasa ECA. Data diperoleh dengan metode interview menggunakan teknik rekam dari penutur ECA di Kairo dan Ismaili. Metode analisis yang dipilih adalah metode distribusional, yaitu metode analisis data yang berupa penghubungan antarfenomena dalam bahasa itu sendiri. Adapun hasilnya adalah bahwa di dalam bahasa ECA terkandung beberapa pola kata yang pola-pola itu perwujudannya menjadi sangat beragam. Keberagaman tercermian bahwa $\mathrm{V}$ bisa diisi oleh vokal [a], [i], dan [u], $\mathrm{K}$ bisa diisi oleh seluruh konsonan dalam bahasa ECA. Dalam verba perfek terdapat pola verba berafiks pronomina persona pertama tunggal dan pronomina persona kedua laki-laki tunggal yang hanya dapat dibedakan berdasar konteks. Ditemukan suatu fenomena bahwa dalam ECA hanya ditemukan kata bersuku KV, KVK, KVVK, tidak ditemukan kata bersuku KKV, KKVK.
\end{abstract}

Kata kunci: morfologis, pola kata, suku kata, bahasa Arab Mesir, distribusional

* Western Asia Department, Faculty of Cultural Sciences, Universitas Gadjah Mada 


\section{INTRODUCTION}

Arabic in Egypt has a standard variety or Modern Standard Arabic (MSA) and an ammya variety or the Egyptian Colloquial Arabic (ECA) (Prochazka, 2006: 424). Morphologically, MSA has experiences inflectional and derivational processes (Ma'nawi, 1999: 115). The ECA used by the Egyptian people in everyday life in informal situations is also assumed to have undergone inflectional and derivational processes. Both processes produce words which have patterns in the ECA. Morphologically, the ECA has certain word patterns. It has unique patterns that many speakers outside Egypt, especially Indonesian people, have not been able to master them.

In accordance with the aforementioned background and the problems, the objective of this study is to map the morphological rules of the ECA which are currently used to communicate, particularly in a global context. The results of this study will allow Indonesia people in particular and the world community in general to communicate with the Egyptian people in informal situations.

The research data were in the form of words that were functional in the sentences of ECA. This means that these words were used to communicate among the speech community of ECA. Data sources in the form of utterances were taken from the language of Egyptian people, especially in Cairo and Ismailis, spoken by students of Suez Canal University of Ismaili and students of the Cultural and Information Centre (PUSKIN) Cairo who used ECA in their daily interactions. The data were obtained between June 6 and June 21, 2013 through interviews with recording techniques. The data were analyzed with distributional method, a method of data analysis which connects phenomena in a given language by considering the context of the language that performs its functions as a means of communication (Sudaryanto, 1982: 13). Furthermore, the realization of the making of connection pattern between phenomena of the ECA words was based on Gadalla's model (2000) which divides word into consonant $(\mathrm{C})$ and vowel (V). Meanwhile, the results of data analysis were presented using informal method, a method of reporting by using academic language.

Morphological research on the Egyptian Arabic was conducted by Hafez (2008) who investigated the phonological and morphological integration of borrowed elements into the Egyptian Arabic. From this study it was found that absorption element Egyptian Arabic was integrated through derivation and inflection as the original Arabic morphemes.

Habash et al. (2012) conducted a quantitative research based on computational analysis of the ECA morphology. The result showed that the Egypt Colloquial Arabic (ECA) was different from MSA phonologically, morphologically, and lexically and did not have a standard orthography. This computational analysis expanded the existing means, namely the lexicon of Egyptian Arabic, and followed the guidelines of speech used by the Linguistic Data Consortium for Egyptian Arabic. Gaddala (2000) made a morphological comparison between MSA and ECA. In conclusion, morphologically they were grouped into general findings, basic phonology and morphology, verbal morphology, nominal morphology, adjectival morphology, closed-class morphology. In general, the difference between the two (MSA and ECA) was more dominant at the phonological level than at the morphological level. Both underwent changes that can be made into patterns. Other differences of ECA from the standard Arabic is the absence of inflectional ending, rare appearance of duality, and similarity of plural markers for personal pronoun on verbs and adjectives, and there is no difference for ism tafdil (elative noun), ism zaman (noun of time), dan ism makan (noun of place).

Morphology in linguistics belongs to grammatical level. Bauer (1988: 24-25) as well as Afrizal and Ma'ruf (2014: 107) state that a verb is formed by root element in the form of several consonants added with transfixes in the form vowels which are sometimes added with suffixes. Morphology is not only to determine the form of words, but also to classify units used in changing the word form. Similarly, morphology is used as a set of rules that postulated by linguists to describe the change in the form of words.

Morphologically, Arabic consists of lexical categories, namely ism (noun), f'l (verb), and charf (particle). Arabic words are also divided based on number, type, and tense (al-Galayaini, 1987: 6, ElDahdah, 1981: 4). 
Therefore, this article is different from the studies explained above. The differences are as follow. Hafez discussed the phonological and morphological integration of borrowed uptake in the ECA. Habbash compared phonology and morphology of the MSA with ECA quantitatively. Gaddala discussed the ECA morphological comparison with MSA. Bauer discusses affixation in the verb roots. Afrizal and Ma'Ruf discussed morphemes in the standard Arabic. Meanwhile, this article discusses the word patterns of the ECA, i.e. verbs, nouns, and particles based on their syllables. The patterned words include verbs of perfective (ma:dhiy), imperfective (mudha:ri'), and imperative (amr) of trilateral shahih (sound verb / perfect / normal), nouns of mutasharrif (variable noun/conjugated, inflected ) and ghairu mutasharrif (invariable noun/uninflected). The patterned particles only include ma'na forms: (Letter of signification (the conjunction and preposition)).

In Arabic there are three lexical categories, namely verbs, nouns, and particles (Al-Galayaini, 1987: 6, El-Dahdah, 1981: 4, al-Jarim, 1948: 16). Meanwhile, Van Valin (2001: 6) states that the constituents of sentence can be a noun or noun phrase, a verb or verb phrase, and a preposition or prepositional phrase. It is clear that noun or noun phrase, verb or verb phrase, and preposition or prepositional phrase are lexical categories if they function as fillers in the sentence. Otherwise, the lexical category includes nouns, verbs and prepositions or other particles that are not included in nouns and verbs. Based on this discussion matters, the following discussion is based on categories of nouns, verbs and particles.

\section{Verb pattern}

In Arabic, the verb always contains the first, second, and third personal pronouns. Based on its existence, personal pronoun can be explicit or implicit. Based on its gender, personal pronoun can be masculine or feminine. Based on its number, personal pronoun can be singular or plural. Personal pronoun can also exist in perfect, imperfect, and imperative verbs.

\section{Perfect Verbs (ma:di)}

The perfect verb in ECA can be seen in the following data (1).

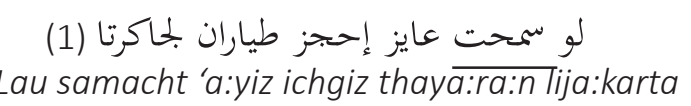

'Excuse me, I'd like to book a flight to Jakarta'

The word samacht 'let, permit' on sentence (1) has a verb root composed of three consonants [s-m-ch]. The triconsonantal verb root [s-m-ch] indicates both bound morpheme and discontinuous morpheme. It is called bound morpheme for it cannot stand alone as a word but is always attached to some other affixes and it is called discontinuous morpheme for the verb's root morpheme since it is interrupted by the insertion of vowel affixes. Affix that is inserted into the verb root is a transfix in the form of vowel [-a-a-]. The root [s-m-ch], therefore, gets the transfix and becomes [samach]. The word samach is a combination between the root [s-m-ch] and the transfix [-a-a-], which forms a perfect verb. On that basis, the perfect verb is patterned CV-CVC. The verb samach is a perfect verb containing the third-person singular male pronoun (he). Therefore, the third-person singular male pronoun is implied in the verb samach with the marker [- - - $\phi]$. On data (1), the verb is attached by phoneme / $\mathrm{t} /$ (samacht). The phoneme $/ \mathrm{t} /$ indicates a marker showing the second-person singular male pronoun (you). Gadalla (2000:66) suggests that phoneme $/ t /$ in addition to representing the second-person singular male pronoun (you). It also represents the first-person singular, male and female pronouns (I). Whether the phoneme /t/ means the first-person singular male pronoun or the second-person singular male pronoun, it can be distinguished by the context (Ma'ruf, 2014:8). The first-person singular female pronoun is encoded / ti/, while the second-person singular, male and female pronouns are encoded $/ \mathrm{tu} /$. The first-person plural pronoun is encoded $/ \mathrm{na} /$.

Thus, the perfect verb patterns in ECA include (1) CV-CVC (the third-person singular male pronoun) (2) CV-CVC-C (the secondperson singular male pronoun and the firstperson singular, male and female pronouns). (3) 
CV-CVC-CV (the first-person plural, male and female pronouns, the second-person singular female pronoun, and the second-person plural, male and female pronouns). $\mathrm{C}$ on the second pattern is always filled by $/ \mathrm{t} / \mathrm{and} \mathrm{CV}$ on the pattern (3) can be filled with /ti/,/tu/, and /na/. The verb samacht can also contain the first-person singular, male and female pronouns (I). The verb turns into samachti when it contains the secondperson singular female pronoun. The verb turns into samachtu when it contains the second-person plural, male and female pronouns. The verb turns into samachna when it contains the first-person plural, male and female pronouns. When followed by personal pronoun $/ \mathrm{t} /$ for the second singular person, the consonant $/ t /$ emerges. This personal pronoun comes from inta and attaches to the verb located at the end of the word to turn into samacht.

\section{لا انا قست ثمانية و أربعين بس (2) \\ La ana ?ist tamania wa arbaiin bas \\ 'I only measure the 48'}

The verb ? ist 'I measure' in sentence (2) shows the pattern CVC-C. C in the last position indicates the first-person male and female pronouns. When standing with personal pronoun that is encoded $\mathrm{C}$ and $\mathrm{CV}$ representing $/ \mathrm{t} /$ and $/ \mathrm{tu} /, / \mathrm{ti} /$ or $/ \mathrm{na} /$, a vowel /i/ emerges from the origin /a/ with the verb's origin ?a:s. This is because this verb includes a middle defective letter (illah) $y a$, and vowel /i/ emerges when it meets personal pronouns encoded $\mathrm{C}$ and $\mathrm{CV}$. Based on the above analysis, the patterns of perfect verb can be different due to its consonant constituents, i.e. soft consonant (illah) or undefective letter (salim).

\section{Imperfect Verbs (muda:ri')}

The muda:ri verb (imperfect) in ECA is characterized by harf muda:raah (?, n, y, and t) which are at the beginning of the verb with vowel /i/ for all markers of personal pronouns so it can be patterned (?, n, y, t) CCVC. Meanwhile, the perfect form for mujarrad pattern (basic form) is always in the initial vowel/a/. The muda:ri verb is used for the present time (al-ha:l) and future time (mustaqbal) (El-Dahdah, 1981:114) as illustrated by the following example.
إحجز طياران لجاكرتا (3)
?ichgiz thaya:ra:n lija:karta?

'I'd like to book a flight to Jakarta

The verb ?ichgiz 'I order' in sentence (3) indicates that the verb contains the first-person singular personal pronoun with a prefix marker /?/ with a vowel /i/ patterned CVC-CVC, thus all other verbs containing personal pronoun follow this pattern as shown in the following data.

على إي خطوط تحب تحجز؟ (4)

'ala iyye khathu:th tuchib tichgiz?

'What flight do you book?'

On sentence (4), the word tichgiz 'you order' is an imperfect verb with a second-person male pronoun. When the verb muda:ri (imperfect) with future tense (mustaqbal) get a prefix /hi/, the sentence is illustrated by the following data (5).

هناخذ منك أربعتلاف مصري (5) hina'khudz minka arba'tila:f mashriy

'We will ask for 4 thousand Egyptian pounds'

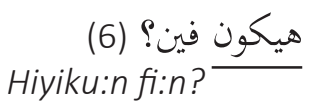

'Where is him?

The hina 'khudz and hiyiku:n in sentences (5) and (6) and the like belong to imperfect verb started with /hi-/. Their imperfect verbs are $n a^{\prime} k h u d z$ and $y i k u: n$. The personal pronoun in na'khudz is the first-person plural pronoun, while the personal pronoun in yiku:n is the third-person singular male pronoun. The addition of particle $h i$ is meant to indicate the future tense (mustaqbal).

\section{Imperative Verb (amr)}

The imperative verb (amr) is a verb denoting a command delivered by mutakallim (the speaker), the person who gives command, to mukha:thab (the listener), i.e. the second male or female person $(\mathrm{m} / \mathrm{f}-2)$ who is ordered. The pattern of amr (imperative) is derived from the imperfect verb for its middle vowel. Then, the first syllable starts with /?/ with a vowel /i/ or /?/ with a vowel 
$/ \mathrm{u} /$ as a 'pronunciation helper'. The examples are shown in the data (7) and (8) below.

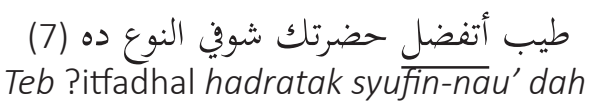

'Please have a look at this model'

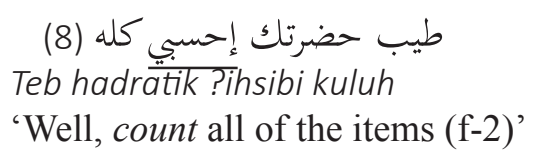

On sentence (8) the word?ihsibi 'count' emerges for the second female person (f-2) since it is in the form of imperative verb. In this case, the imperative verb is used for the second-person female pronoun (f). The imperative verb in the example (8) is patterned CVC-CVC. Meanwhile, the imperative verb in example (7) is patterned CVC-CV-CVC. Sentence (8) indicates a disyllabic pattern, while sentence (7) shows a trisyllabic pattern. Pattern (7) is longer because the verb is derived from a verb that has gained additional affixes, namely [?] with a vowel [i] and [t] with a vowel [a].

Viewed from the presence or absence of its object, verbs are grouped into intransitive verb (lazim) and transitive verb (muta addi). An intransitive verb is a verb that does not needs an object in the sentence (Abdul-Gani, 2010:82). In term of meaning, when a verb can be understood without an object, then it belongs to intransitive verb, as illustrated in the following example.

وتنزل الشارع وترجع (9)

wa tinzil asy-yari' wa tirgi'

'You go down the street and go home'

On sentence (9), the word tirgi' 'go home' is an intransitive verb because it does not require the presence of an object. The imperfect verb in example (9) is patterned CVC-CVC.

The transitive verb (muta'addi) is a verb that requires an object in the sentence (El-Dahdah, 1981:119). To know this is by looking for its meaning if the word requires an object or it is enough to understand without an object. Below is the example of transitive verb:

\section{حضرتك تحب سرير إضافي؟ (10) chadratak tichib sari:r idha:fi: \\ 'You want an extra bed'}

The verb tichib in sentence (10) requires an object to complete the sentence to be understood. The object in the sentence is sari:r idha:fi: 'extra bed'. Thus, the verb tichib belongs to transitive verb (muta addi). When the object is removed, the intent of the verb becomes unclear or incomplete, so chadratak tichib 'you want' only is incomplete. The verb pattern of tichib is CV-CVC. The pattern on sentence (10) is actually originated from CVC-CVC, derived from the imperfect verb tichbib. Because both have similar last consonants, they are then unified by syaddah. In order that vowel /i/ on the second syllable can be pronounced, the previous consonant is pulled back so that it is patterned CV-CVC whose origin is CVC-CVC. Based on the two verbs, there is no specific marker to distinguish between transitive and intransitive verbs in the ECA imperfect verbs.

\section{Noun}

The following discussion of noun pattern is based on the view by Ad-Dahdah (1981: 38) who divides nouns into two categories, namely mutasharrif nouns and ghairu mutasharrif nouns. The mutasharrif nouns include musytaq nouns (derived noun) and ja:mid nouns (inert noun). The musytaq noun is formed from another word through the process of derivation. El-Dahdah (1981:38) explains that musytaq noun is formed from verb, while ja:mid noun is a noun that is not derived from any other word. Nouns belonging to musytaq noun include ismul-fa: 'il, ismul-maf'u:l, sifah musyabbahah, amtsilatul-mubalaghah, tafdi:l, makan, zama:n, nomina alat, dan almashdarul mazid.

The pattern of musytaq noun (derived noun) in ECA is presented in the following discussion. Participle nouns are divided into active participles and passive participles (Al-Gulayaini, 1976:182,186). The pattern of active participle word usually consists of two syllables. The first syllable is an open long vowel /a:/ and the second syllable is a closed vowel $/ \mathrm{i} /$ with a pattern CVVCVC when it comes from a triliteral verb. The examples can be seen in data (11) and (12) below. 


\author{
لو رايح بس؟ (11) \\ Lau ra:yich bas
}

'How about leaving?'

(12) عايز إحجز طياران
'a:yiz ichgiz thaya:ra:n
'I want to book a plane'

On sentences (11) and (12), the words ra:yich' 'leave' and 'a:yiz 'want to' have a pattern CVVCVC derived from triliteral verbs formed into active participle with a pattern CVV-CVC. When derived from the above-triliteral verbs, active participle is formed with a pattern following its imperfect verb pattern by replacing harf mudha:ra'ah with prefix /m/ (El-Dahdah, 1981: 80).

The pattern of passive participle noun is a closed first syllable with a middle vowel /a/, and a closed second syllable with a middle long vowel $/ \mathrm{u}: /$, transforming into a pattern maC-CuuC or $\mathrm{mVC}-\mathrm{CVVC}$. The example is presented in data (13) below.

طيب إيه الأورق المطلوبة علشان التقديم؟ (13) Te:b, ih I-auru' I-matlu:bah alsyan al-taqdi:m

'Well, what documents to be submitted?'

The word l-Mathlu:bah 'requested, submitted' is a word that is categorized as feminine definite passive participle. Its masculine indefinite form is mathlu:b. The word is patterned $\mathrm{maC}-\mathrm{CuuC}$ from the word thalab 'ask for' which indicates 'the passive'. Therefore, this noun belongs to the passive participle. When the verb is derived from the above-triliteral verb, its passive participle is formed with a pattern as its imperfect pattern, i.e. by changing the harf mudha:raah /?, n, y, and $\mathrm{t} /$ into $/ \mathrm{m} /$ and changing the vowel $/ \mathrm{i} /$ on the last syllable of its imperfect form into the vowel $/ \mathrm{a} /$.

The next noun is masdar mazid as presented in the following sentence.

طيب دلوقت وزن زيادة؟ (14) Teb dilwa'ti wazn ziya:dah?

'Well, if there's more/additional load'
On example (14), the word 'ziya:dah 'more, additional' is a noun belonging to masdar mazi:d derived from the verb za:d 'increasing'. The masdar (original noun, noun of action, infinitive) is an ism (noun) which indicates events that are not bound by a definite time (Al-Gulayaini, 1976:164). This is in contrast with verb ( $\left.f^{\prime} l\right)$ which is bound by time, either past, present or future, which can be understood in the context of the sentence, while the meaning of the noun is not bound by time.

The infinitive pattern on sample (14) is $f^{\prime}$ 'a:lah that is categorized as feminine whose masculine form is fi'a:l with a pattern CV-CVVC coming from the perfect verb fa: 'il (Gadalla, 2000:134). Gadalla (2000:133-134) suggests that in addition to the mentioned pattern there are still 16 infinitive patterns existing in ECA.

The other noun is shifah musyabbahah (similar quality/assimilate epithet) as seen from the data (15) below.

\section{أنا دخلت كنتاكي هو نضيف (15) Ana dakhalt kentaky huww nadi:f. 'I entered Kentaky, it's clean'}

Sentence (15) contains the word nadhi:f 'clean' which belongs to shifah musyabbahah, i.e. adjective that is unchanged and is unrelated to time. Shifah musyabbahah is a noun that resembles ism fa: 'il (active participle) in term of adjective, but shifah musyabbahah tends to have a sense of fixed adjective (Al-Gulayaini, 1976:189). Meanwhile, the active participle is more likely to mean temporary adjective. The word nadhi:f on data (15) is a syifah musyabbahah word with a pattern CV-CVVC. The pattern is derived from a triliteral perfect verb whose root is [n-dh-f].

A noun that is associated with the instrument or tool is called ism alat (noun of instrument) as shown in data (16) below.

$$
\text { عايزة جولة بالمركب (16) }
$$

'(You) want to walk around with the boat'.

Data (16) contains an ism alat, i.e. a noun that shows the instrument of the word that makes it up 
(Al-Gulayaini, 1976:210). Ism alat on sentence (16) is el-markab 'boat'. The noun is categorized as a ta'rif noun whose takta'rif form is markab. The ism tool of markab has a pattern CVC-CVC whose first consonant on its first syllable is $/ \mathrm{m} /$, followed by vowel /a/. In addition to vowel /a/ in the first syllable, vowel /i/ and vowel $/ \mathrm{u} /$ are also found in the first syllable, for instance: michra:t 'pirate' and mufta:ch 'key' (Gadalla, 2000:140).

A noun that is associated with time is called ism zaman or noun of time (El-Dahdah (1981:4). Ism zaman is a noun that describes the time of activities undertaken by the subject (Al-Gulayaini, 1976: 207). The example ism zaman is illustrated in the following data (17).

دلوقتي ميعاد خروج (17)

dilwa'ti mi:'a:d khuru:g

'Now, it's going home time'

On data (17), the word mi:'a:d 'appointment time' refers to a noun of time. The noun is patterned CVV-CVVC. The noun is formed from the verb wa'd 'promise' whose root is [w, ', d]. The consonant $/ \mathrm{w} /$ is a semi-vowel phoneme $/ \mathrm{w} /$ that turns into vowel /i/ as it follows vowel /i/ that follows the previous consonant $/ \mathrm{m} /$. For Arabic speakers, the pronunciation of phoneme /i/ which is followed by semi-vowel phoneme $/ \mathrm{w} /$ is difficult, while for non-Arabic speakers, it is possible that such a pronunciation is not difficult. Therefore, in Arabic pronunciation, a semi-vowel phoneme that follows phoneme $/ \mathrm{i} /$ is transformed into phoneme /i/. As a result, on the first syllable of the word, there are two /i/ vowels so it becomes mi: 'a: $d$ with a pattern CVV-CVVC.

Ism tafdhi:l that El-Dahdah (1981:4) refers to as noun or preference of superiority is a noun which indicates "more/much" or "the most" (AlGalayaini, 1987: 199), such as the word $a$ ? rab in data (18), and the word ?a?al in data (19) as follows.

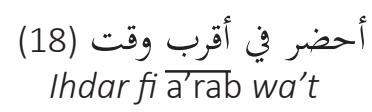

'I'll let you know as soon as possible'

\section{أقل حاجة عشرين فرد (19) \\ ?a?al hagah isyrin fard \\ 'At least twenty people'}

In examples (18) and (19), the word $a$ ? rab 'as soon as possible, closer (time)' and the word ?a? al 'at least' belong to ism tafdhi:l denoting more or the most. Both words are patterned CVCCVC. The first consonant in the first syllable of ism tafdhi:l is always in the form of hamzah phoneme /?/ with a vowel /a/.

The noun pattern of mutasharrif musytaq has been alreasdy discussed. The following discussion is about noun patterns of mutasharrif jamid. ElDahdah (1981:38) states that jamid noun is a noun that is not derived from verb. Its types, according to Al-Ghulayaini (19872: 5-6), include ism 'alam, ism jins, and original triliteral mashdar.

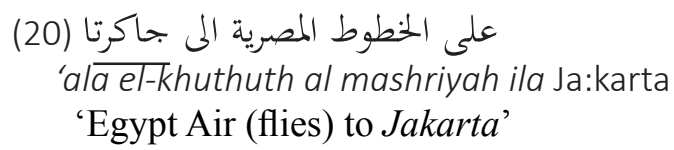

The word 'Jakarta' on data (20) is an ism 'alam because the word is a noun that is used for naming a city. The noun is patterned CVV-CVCCV. All geographical names (cities, countries, islands, rivers, mountains, seas) belong to ism 'alam. Therefore, ism 'alam has an abundant number of patterns. Although there are so many patterns of ism 'alam, ECA has no pattern with a syllable of CCV.

طيب خلاص اتني واحدة اباية مقاسي ثمانية اربعين (21) Theb, khala:sh itni: wa:chidah ?aba:yah maqa:si:tsama:niyaharba'i:n.

'Well, give me one abaya size 48'

The word ?aba:yah on data (21) is an ism jins because the noun has smaller sections or no subordinate, for example aba:yah su'u:diyah 'Saudi abaya'. Al-Ghulayaini (1987:108) explains that ism jins is a noun that is not confined to a single noun and ignore other nouns. The noun is patterned CV-CVV-CVC. In ECA, this noun has so many patterns, for example rajulun with a pattern 
CV-CV-CVC, ?imra? atun with a pattern CVC-CV$\mathrm{CV}-\mathrm{CVC}$, etc.

انا هقيس و شوف و قول للحضرتك (22)

?ana hai:s wa syu:f wa ?u:l lichadhratik

'I am going to measure, see, and tell you'

On data (22) the word ?aul 'saying, utterance' which is categorized as mashdar (infinitive / original noun) is derived from the verb qa:la 'to say'. Mashdar on sentence (22) is a noun that serves as a verb. Its pattern is CVC. A mashdar patterned CVC occurs when the middle consonant of its verb is illah consonant (?ali:f, $w a u$, and $y a$ ?). When the middle consonant of its verb is not illah consonant, then its mashdar will has a pattern CVCC.

As noted in the discussion above, nouns are divided into mutasharrif nouns and ghairu mutasharrif nouns. The mutasharrif noun has two types, namely musytaq noun and ja:mid noun. The following discussion presents ghairu mutasharrif noun pattern. El-Dahdah (1981: 38) states that ghairu mutasharrif noun include personal pronouns, demonstrative pronouns, alismul-maushu:l, ismusy-syarth, ismul-istifha:m, al-kina:yah, adh-dharfu, and ismul-'ada:d.

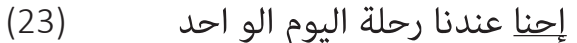 Ichna 'indana: richlah el-yaum wl-wa:chid ' $W e$ have a full-day tour schedule'.}

The word ichna: 'we' on data (23) is the first-person plural pronoun. The word is patterned CVC-CVV. In addition to the first-person plural pronoun, there are also the first-person singular pronouns, i.e. ana 'I', the second-person singular male pronoun inta, the second-person singular male pronoun inti, the second-person male and female plural pronouns intu, the third-person singular male pronoun huwwa, the third-person singular female pronoun hiyya, the third person male and dual female and plural pronouns humma. Therefore, the ECA second-person (both male and female) dual and plural pronouns use intu, while the third-person (both male and female) dual and plural pronouns use humma.

$$
\begin{aligned}
& \text { لا دي في الدرجة إقتصادية (24) } \\
& \text { La? di Fid-daragah al-?i'tisha:diyah } \\
& \text { 'No, this is in economy class' }
\end{aligned}
$$

On data (24) the word $d i$ 'this' indicates an isya:rah (demonstrative) that by Gadalla $(2000: 217)$ is referred to as demonstrative pronoun. The word has a pattern CV. Gadalla (2000: 217) states that $d i$ is used to indicate a close-range demonstrative of singular feminine pronoun. In addition to demonstrative pronoun $d i$, there are also other demonstrative pronouns like $d a(\mathrm{~h})$ 'this', $d u: l$ 'this', ducha 'that', dicha 'that', and ducham 'that'. The $d a$ is used for a close-range demonstrative of singular masculine pronoun. The $d u: l$ is used for a close-range demonstrative of dual and plural pronouns, both masculine and feminine. It is possible for di to turn into diyya and $d a$ to become dawwa: The ducha, dicha, and ducham are used for long range demonstrative. The ducha is used for third singular masculine, dicha for the third singular feminine, and dicham: for the third plural masculine and feminine.

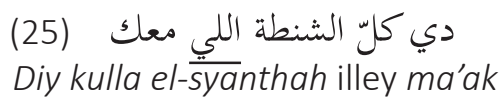

'These are all bags that you are carrying?'

On data (25) the word illey is an ismul-maushu:l (conjunction) that by Gadalla (2000:2016) is referred to as relative pronoun. The word is patterned CVC-CV. This pattern is used for single, dual, and plural, male and female nouns.

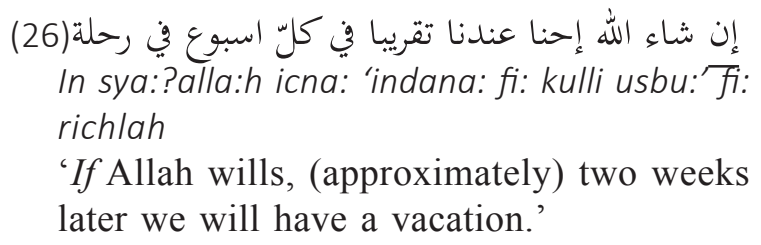

The word in on data (26) is the syart (condition). It is usually followed by a clause and other clauses. A clause that follows syart is called conditional clause and the other clauses are referred to as the core clause. The syart word is patterned CVC. 
و كام بقي سعر الأبيا (27)

Wa ka:m baqiy si'rul-'Abaya?

'So, how much is the abaya?'

The word $\mathrm{ka}: \mathrm{m}$ in data (27) is the ism istifham (interrogative). The word is patterned CVVC. Gadalla (2000: 230) states that in addition $\mathrm{ka}: \mathrm{m}$, there are other interrogative particles, including yatara, ?anhu 'which one' used for the third-person singular male pronoun, ?anhi 'which one' for the third-person singular male pronoun, and ?anhum 'which' for the third-person plural, male and female pronouns.

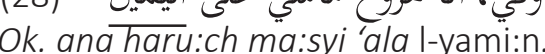

'Okay, I will walk on the right side'

On data (28), the word el-yami:n 'right side' is in the form of takrif whose taktakrif form is yami:n. The word is an adverb of place (Gadalla: 2000: 227). The word is patterned CV-CVVC.

\section{لو رايح جاي حولي أربعتلاف (29) \\ Lau ra:yich gay chawali arba'tila:f \\ 'If commuting, it's around four thousands'}

On data (29), the word arba' 'four' is a number with a pattern CVC-CVC. Numbers with a pattern CVC-CVC belong to cardinal numbers. Meanwhile, numbers with a pattern CVV-CVC belong to ordinal numbers, such as wa:chid 'first', ta:niy 'second', ta:lit 'third' and so on.

\section{Particle}

The particle in the Arabic linguistic terminology is known as charf (El-Dahdah, 1981:11). Talking about charf in Arabic linguistic perspective, the word charf has two senses, i.e. (1) consonant, and (2) particle. Charf in the perspective as a particle is, of course, identified as a word. Therefore, in this case charf (particle) can stand alone, but the particle only raises its meaning when it is bound or connected to other words. El-Dahdah (1981:23) states that particles do not have a clear meaning without other words in a sentence context.
Some of these include lau 'if', la: 'no', bas 'only'. As stated above, only ma'na: particle is discussed. El-Dahdah (1981:26) breaks churu:fulma'a:niy down into two categories, namely a:milah and ghairu 'a:milah. Upon consideration of space limitation, this discussion focuses only on 'a:milah. According to El-Dahdah (1981:26), 'a:milah can exist with noun, verb, and both noun and verb. 'A:milah that specially exists with noun includes al-jarr (preposition), an-nasakh (letter of annulment/particles that change the subject into the accusative), an-nida:? (letter of call/vocative article), and istisna:? (letter of exclusion/particle of exception). 'A:milah that specially exists with verb includes al-jazm (letter of elision/particle of apocope/particle of jussive), an-nashb (letter of opening/subjunctive particle). 'A:milah that exists with both noun and verb includes al-'athf (letter of attraction/conjunction/copulative). The particle patterns discussed based on the data are as follows.

\section{كام ساعة هنكون في المية؟ (30)} Kem sa:'ah hiniku:n fil-miyah

'How many hours we were in the water (the Nile)'.

On data (30) the word fi: belongs to aljarr (preposition). Preposition on sentence (30) has a pattern CVV. In addition to that pattern, there are also other patterns including $\mathrm{CV}, \mathrm{CV}-\mathrm{CVV}, \mathrm{CVC}$, CVC-CVV, and CVV-CVV. Prepositions with a pattern $\mathrm{CV}$ occur in prepositions $l i$ 'for (eg. for you)', $b i$ 'with, $k a$ 'like/as'. Prepositions with a pattern CV-CVV occur in ?ila: 'to (eg. travel to)', 'ala: 'on (top of)', and khala: 'except/unless, 'ada: 'except, but'. Propositions with a pattern CVC occur in 'an 'about' and min 'from'. Propositions with a pattern CVC-CVV occur in chatta: 'until'. Prepositions with a pattern CVV-CVV occur in cha:sya: 'except'. Some prepositions as mentioned above have a dual category. Words with double categories, in addition to be categorized as preposition, they are also categorized as exceptions. These prepositions apear in the words khala:, ada:, cha:sya:, and khala:

$$
\text { أنا مش هقدر أرجع تاني لأنّ بيتي بعيد (31) }
$$


?Ana musy haqdir ?argi' ta:niy li?anna baitiy ba'i:d

'I cannot go back home because my home is far away.'

On data (31) the word li? anna 'because' belongs to nasach (letter of annulment/particles that turn the subject into the accusative and the predicate into the nominative). These particles are patterned CV-CVC-CV.

العفو يا فندم (32)

Al-'afwu ya:fanda:m

'I'm sorry, $O$ Mister'.

On data (32) ya: belongs to an-nida:? (letter of call/vocative article), i.e. particles used for calling. The particles are patterned CVV.

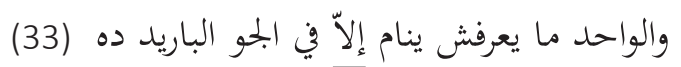
Wal-wa:chid ma: yi'rifsy yina:m illa: fil-jawwilba:rid dih

'And Wachid cannot sleep except in the cold.'

On data (33) the word illa belongs to istitsna:? (exception) which makes an exception (in cold temperature) to the previous clause (Wachid cannot sleep). It means Wachid can only sleep in a cold temperature. This particle is patterned CVC-CV.

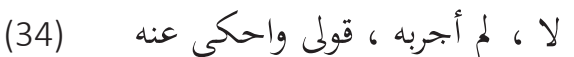 La? Lam igarribhu, u:liy wachkiy 'anhu}

'No, I have not tried it, say and tell me (about it).'

On data (34) the word lam belongs to jazm (jussive particle), i.e. a particle which jussives the verb igarrib 'to try'. The particle is patterned CVC.

طيب خلاص أنا هأخذ العباية و هأخذ الطرحة (35) Theb, khalash. ?āna: hi?ikhudz el-'aba:ya wa hi?ikhudz el-tharacha

'OK, I will take the abaya and I will take the hijab'
On data (35), the word wa is an al-athf (letter of attraction/conjunction/copulative) that onnects two verbs of hi?ikhudz (I'll take). The conjunction is patterned CV. As stated above, such a conjunction can connect a verb with another verb and a noun with another noun. The following data present a conjunction of noun with another noun(s).

\section{لنظام الوجبات فيه فطار و عشاء مع بعضا (36) Lin-nidha:m wagaba:t fi:hi fitha:r wa 'asya:? ma'a ba'dhan \\ 'In connection with our meal, we have breakfast and dinner together.'}

On data (36) the word $w a$ is a conjunction that connects noun fitha:r 'breakfast' and 'asya:? 'dinner'. This conjunction is patterned CV. As noted in data (35), $w a$ is a conjunction that connects a verb with another verb(s), while wa on data (36) connects a noun with another noun(s).

The ma'ani particle patterns in ECA have been discussed above. The following discussion demonstrates a particle which is widely used in ECA, i.e. the negation particle. As noted in data (34), i.e. La? Lam igarribhu, u:liy wachkiy 'anhu 'No, I have not tried it, say me and tell me (about it)', the word lam belongs to jazm particle that negates a clause in the future so that the meaning is 'not yet'. In the ECA language, there is another negation particle, i.e. ma: ... sy 'no'. Unlike lam 'not yet' which is always followed by an imperfect verb, negation particle $m a \ldots s y$ 'no' can be inserted by a verb and preposition. Negation particle ma: ... sy 'no' that is inserted with a verb can be seen in the word ma: yi'rifsy on data (33), i.e. Wal-wa:chid ma: yi'rifsy yina:m illa: fil-jawwilba:rid dih (Dan Wachid cannot sleep except in the cold), and particle $m a$ : ... sy that is inserted with preposition can be seen in the word ma: fi:sy 'no/ nothing' in data 37 below.

\section{ما فش مشكلة (37) ma: fi:sy musykilah}

'There is no problem there'. 


\section{CONCLUSION}

After analyzing ECA words morphologically, the conclusion is outlined in the order of the discussion above, i.e. verb (triliteral), noun (mutasharrif and ghairu mitasharrif), and particle (ma'na).

In term of verbs, the patterns are few and simple. The verb madi (perfect) has two patterns, namely (1) the monosyllabic, i.e. consonant - vowel - consonant (CVC), and $(r)$ the disyllabic with the patterns of consonant-vowel and consonantvowel-consonant (CV-CVC). In the second pattern (CV-CVC), the first syllable is in the form of open syllable with a vowel /a/ or $/ \mathrm{i} /$, and the second syllable is in the form of closed syllable whose vowel between the two consonants is /a/ and / $\mathrm{i} /$.

The mudha:ri' verb (imperfect) only has one pattern, i.e. CVC-CVC. The first syllable is always preceded by charf mudha:raah, i.e. prefix marker of personal pronouns [?, $\mathrm{n}, \mathrm{y}, \mathrm{t}]$, then followed by vowel $/ \mathrm{i} /$, while the second syllable is filled by vowels $/ \mathrm{i} /$, , a/ or $/ \mathrm{u} /$. Imperfect verbs with such a pattern are used to symbolize the meaning of present time. Meanwhile, to symbolize the meaning of future time, the verb is added with $/ \mathrm{h} /$ with a vowel /i/.

Imperative verb that is used to command the listener occur with the pattern CVC-CVC. V on the first syllable is filled by vowel $/ \mathrm{i} /$ or $/ \mathrm{u} / \mathrm{V}$ on the second syllable is filled by $/ \mathrm{i} /, / \mathrm{a} /$, and $/ \mathrm{u} /$. Such a pattern indicates an imperative verb pattern of shahih (sound verb/perfect/normal).

The patterns of mutasharrif noun are CVV$\mathrm{CVC}$ for active participle and $\mathrm{CVC}-\mathrm{CVC}$ for passive participle. Both patterns are derived from triliteral verbs. Its mazid mashdar (above triliteral) has a pattern CV-CVVC. The sifah musyabbahah (similar quality/assimilate epithet) has a pattern $\mathrm{CV}-\mathrm{CVVC}$, ism alat has a pattern CVC-CVC, and ism zaman has a pattern CVV-CVC. Meanwhile, particles have a pattern CVV or CVC. The ghairu mutasharrif noun does not have a fixed pattern so it cannot be analogized. Similarly, the particle also does not have a fixed pattern.

\section{REFERENCES}

Abdul-Gani, Aiman Amin. (2010). As-sarful-Kafiy. Kairo: Dar at-Taufiqiyah lit-turas.
Afrizal, Mohamad dan Amir Ma'ruf (2014). "MorfemMorfem Triliteral Bahasa Arab". Humaniora Volumne 26, Nomor 1, Februari 2014. Hlm. 93 - 108. Yogyakarta: Unit Pengkajian dan Publikasi Fakultas Ilmu Budaya Universitas Gadjah Mada.

Bauer, Laurie. (1988). Introducing Linguistic Morphology. Edinburgh: Edinburgh University Press.

El-Dahdah, Antoine. (1981). A Dictonary of Arabic Grammar in Carts and Tables. Beyrut: Librairie du Liban Publishers.

Gadalla, Hassan A.H. (2000). Comparative Morphology of Standard and Egyptian Arabic. Lincom Europa.

Al-Gulayaini, Asy-Syaikh Mustafa. (1976). Jami' ad-Durus al-Arabiyyah: Vol. I,II. Beirut: Maktabat Ashriyyah.

Habash, Nizar, Ramy Eskander, dan Abdelati Hawwari. (2012). "A Morphological Analyzer for Egyptian Arabic", Proceedings of the Twelfth Meeting of the Special Interest Group on Computational Morphology and Phonology (SIGMORPHON2012), pages 1-9, Montre'al, Canada, June 7, 2012. Montre'al: Association for Computational Linguistics.

Hafez, Ola. (2008). "Phonological and Morphological Integration of Loanwords into Egyptian Arabic" dalam Egypte Monde Arabe Première série, Les langues en Égypte, [En ligne], le 08 juillet 2008 p. 383-410. Cairo: Université du Caire.v

Al-Jarim, Ali, Mustafa Amin. (1948). An-NahwulWadih. Fi Qawa'idil-lugah Al-Arabiyah al-juz'ul awwall. Kairo: Dar al-Ma'arif.

Kridalaksana, Harimurti. (2008). Kamus Linguistik. Jakarta: Gramedia Pustaka Utama.

Ma'nawi, Arief. (1999). "Ciri-ciri Morfologis Bahasa Arab sebagai Anggota Rumpun Bahasa Semit". Humaniora No. 12. September-Desember 1999. pp. 115 - 121. Yogyakarta: Fakultas Sastra Universitas Gadjah Mada.

Ma'ruf, Amir. (2014). "Identity, Facts, and Challenges of Arab Culture: A Case Study of Grammatical Meaning of Word in Egyptian Colloquial Arabic. The International Seminar on Arabic Culture 2014: The Arabic Culture Identity Facts and Challenges. Yogyakarta: Faculty of Cultural Science Universitas Gadjah Mada.

Prochazka. S. (2006). "Arabic" in Encyclopedia of Language and Linguistics 2 Edition (423). London: Elsevier. 
Humaniora, Vol. 27, No. 2 Juni 2015

Sudaryanto, (1982). Metode Linguistik: Kedudukannya, Aneka Jenisnya, dan Faktor Penentu

Wujudnya. Yogyakarta: Fakultas Sastra dan Kebudayaan UGM.
Van Valin, Robert D, JR. (2001). An Introduction to Syntax. Cambridge: Cambridge University Press. 